\title{
GENUINE PROTECTION OF INTERNATIONAL REFUGEES: A STUDY OF THE INFLUENCE OF WESTERN STATES ON THE MANDATE OF THE UNHCR
}

\author{
Sugiyama Kanako*
}

\section{INTRODUCTION}

The aim of this essay is to analyze the principal roles of the United Nation High Commissioner for Refugees (UNHCR). It examines how the mandate of the UNHCR has evolved in the context of recent events in order to balance the protection of the human rights of refugees with the interests of powerful Western states. The crucial fact is that the Western European states, leading donors to the UNHCR, exercise considerable influence on UNHCR policy for it to meet their demands, no matter how such influence limits the capacity of the UNHCR to protect refugees at risk. Western influence has become particularly evident since these states first faced the arrival of an increasing number of asylum seekers in their territories. The states, while restricting their own asylum policy, try to impose on the UNHCR restraints and pressures aimed at controlling its policy and operations. This can clearly be seen in recent UNHCR operations, namely, towards the Tamils, Kurds, Afghans, and Kosovars, where the UNHCR has shifted away from genuine international protection. Furthermore, it can be understood that the recent Western-oriented operations have shaped both the mandate of the UNHCR and the international legal framework for refugee protection as a whole.

This essay is divided into four chapters. Chapter 1 provides a brief survey of the worldwide history of refugee movements and the causes over the past fifty years of an individual's becoming a refugee. It illustrates current refugee flows with the numbers and country destinations, as well as with the geographical proportions of refugee movements in the world. The statistics shown in this chapter indicate that only a small number of refugees seek asylum in the West, while the developing

\footnotetext{
* Adviser to the Japanese Mission to the European Union in Brussels. LL.M. (2003 University of London), Internship at ILO in Geneva (2003) and the UNHCR (2004). I am deeply indebted to Dr. Prakash A. Shah at Queen Mary College, University of London, for supervising my work to a great extent with his valuable comments and advice on earlier drafts of this paper. I also thank my family and friends for their kind support and encouragement throughout my work.
}

Asian Yearbook of International Law, Volume 11 (B.S. Chimni et al., eds.)

(C) 2006 Koninklijke Brill NV. Printed in The Netherlands, pp. 89-121. 
countries receive a much larger number of asylum seekers. The last section then introduces conflicts between, on the one hand, this European current asylum trend and humanitarian obligations which the Western governments are expected to fulfil due to their having ratified the Convention Relating to the Status of Refugees (1951 Convention) and, on the other, certain other international human rights laws.

Chapter 2 sketches the mandates of the UNHCR, the only comprehensive international machinery for providing protection to refugees, and the 1951 Convention, the first established international law related to refugee protection. The chapter also shows other international human rights laws providing safeguards for refugees at risk. Although the UNHCR carries out its policies in accordance with its Statute, it has confronted inevitable changes and challenges in order to adapt its functions to current environments. The problems stem partly from the fact that the tasks of the UNHCR have developed in different ways depending on the location where it operates, given the various attitudes of the respective host governments. For example, the activities of the UNHCR differ considerably in Europe, to which refugees escape from developing countries, from their activities in the developing world, the source of most refugee flows and, in effect, where numbers of people are suffering from daily hardship.

Following these core mandates of the UNHCR, the third chapter discusses the restraints and pressures imposed upon the UNHCR by powerful Western states, and analyzes why the UNHCR is so vulnerable to pressures from these states. Through quoting recent UNHCR preventive operations in various countries, this chapter illustrates and examines the consequences of such policies, and also their impact both on the mandates of the UNHCR and on the international legal framework in the context of refugee protection.

In conclusion, having analyzed certain recent events, the last chapter explores questions arising from the Western-influenced policies towards refugees. Recent UNHCR operations have actually raised the issue that these policies may devalue not only the whole refugee protection regime, but also the UNHCR's raison d'etre. Finally, this essay concludes that the UNHCR has reached the point where it needs to reconsider and re-evaluate its mandates in order for it to provide genuine protection to refugees. It suggests that the UNHCR and the international community elaborate a realistic yet refugee-oriented policy, in particular bearing in mind that, since conflicts and wars seem not to have ended, the number of asylum seekers seems similarly unlikely to decline.

\section{THE REFUGEE PROBLEM IN A GLOBAL CONTEXT}

\subsection{A short history of refugee movements in the twentieth century}

The original refugees who provoked the issue of the "International Protection of Refugees" were those who had fled their own countries because of persecution during the First World War. During and after the Second World War, the increasing number of refugees in Europe, mainly persons displaced by war from Poland and 
other Eastern European countries to Allied-occupied Europe, became the biggest problem in the region. Eventually, this refugee influx resulted in the very first development of an international protection instrument, which subsequently evolved through many events to cover a much wider range of refugees over the world.

In the year 1951, there were merely some 1.5 million refugees, mainly in Europe; the number grew to 20.6 million world-wide at the start of the year 2003. ${ }^{1}$ The first new refugee group, subsequent to two World Wars, consisted of those escaping from the newly-established Communist states in Eastern Europe during the Cold War in the 1950s. At that time, the Western states were generous enough to receive those refugees since then these states could use them as political and ideological opposition to the Communist countries. On the other hand, the second group comprised those fleeing from the developing countries in the 1960s and 1970s. This group of refugees fled their countries of origin due to such reasons as, for example, the struggle to achieve independence from former colonial rulers, or conflicts within newly independent states. Besides, in this period, about ten million people migrated to Europe from the developing countries as guest workers to fill the labour shortage in the aftermath of the Second World War. ${ }^{2}$

Furthermore, it can be seen that more and more refugee exoduses have occurred since the 1970s for a variety of reasons: civil wars, natural catastrophes, poverty, political repression, internal discrimination, and so on. With the help of recent advances in communication and transport, those who fled their countries of origin for such reasons are more likely to seek asylum in the industrialized states, namely, Western Europe, the United States, Canada, and Australia. Such refugee inflows into the developed states had become marked by the 1990s.

\subsection{Analysis of refugee flows in the world}

At the time of writing (2003), it is clearly seen that refugee movement has expanded globally. At the beginning of 2003, the number of people of concern to the UNHCR - including refugees, asylum seekers, returned refugees and Internally Displaced Persons (IDPs) - was 20.6 million, in contrast to 1.5 million in 1951. The geographical breakdown demonstrated by the $\mathrm{UNHCR}^{3}$ in 2003 shows $9,378,900$ refugees are in Asia; 4,593,200 in Africa; 4,403,900 in Europe; 1,061,200 in Northern America; 1,050,300 in Latin America and the Caribbean and, lastly, 69,200 in Oceania. Of this total population of 20,556,700, according to the UNHCR's latest analysis, approximately 1,014,400 applied for asylum worldwide in 2002.

The UNHCR table also indicates the origins of the major refugee populations and the main countries of asylum in 2002. The majority of refugees came from Afghanistan, Burundi, Sudan, Angola, Somalia, the Congo, Iraq, Bosnia-Herzegovina, Viet Nam and Eritrea. 2,481,000 Afghan refugees applied for asylum mainly in

\footnotetext{
${ }^{1}$ Loescher, G., Refugee Movements and International Security (London: Brassey's, 1992), at 9.

2 Ibid., at 9.

3 UNHCR, Refugees by Numbers (Geneva, 2003).
} 
Pakistan and Iran; 574,000 Burundi refugees in Tanzania and the Democratic Republic of Congo; 505,200 Sudanese in Uganda, Ethiopia, the Congo, Kenya, and the Central African Republic; 433,000 Angolans in Zambia, the Congo, Namibia, and the Congo; 429,000 Somalis in Kenya, Yemen, Ethiopia, the UK, the USA and Djibouti; 415,000 Congolese in Tanzania, the Congo, Zambia, Burundi and Rwanda; 401,000 Iraqis in Iran, Germany, the Netherlands and Sweden; 372,000 Bosnians in Serbia-Montenegro, the USA, Sweden, Denmark and the Netherlands; 348,000 Vietnamese in China and the USA and, finally, 316,000 Eritreans sought asylum mainly in Sudan and Ethiopia.

It is worth remarking that a larger number of developing countries receive more refugees than do the developed countries despite the formers' poor economic circumstances. Compared to the size of the national population, the main refugee hosting countries during 2001 were Armenia 1:14, followed by the Congo 1:25, Yugoslavia 1:26, Djibouti 1:27, and Zambia 1:37. In 1992, Malawi received the largest number of refugees: 1:10 as compared to 1:869 for Germany, and 1:3,860 for the United Kingdom. ${ }^{4}$ Moreover, the least developed countries usually host refugees for long periods of time. The countries receiving the largest numbers of refugees in recent years have been Pakistan and Iran, hosting 2.2 million and 1.9 million respectively; these constitute twice as many refugees as there are in all of the countries of Western Europe combined. ${ }^{5}$ A recent prominent example is found in the Eastern European developing countries, Armenia, Albania, and the former Yugoslav Republic of Macedonia, all of which continue to receive a great number of refugees from Kosovo in spite of the not only financial but also social burdens placed upon them by the influx. ${ }^{6}$

Statistics also reveal that a great majority of refugees seek asylum in the world's poorest states; the twenty countries with the highest ratio of refugees have an annual average per capita income of $\$ 700 .^{7}$ In contrast to the developing countries, the number of asylum applications submitted in Western Europe is considerably lower: in 2002, the United Kingdom, the country receiving the largest number of refugees from the developing states among the Western European countries, received 110,700 applications. (The UK government claimed during the year that the number had reached 100,000.) The second-highest was Germany, receiving 71,100. There were 50,800 refugees applying for asylum in France; 37,100 in Austria; 33,000 in Sweden; 26,200 in Switzerland; 18,800 in Belgium; 18,700 in the Netherlands; 17,500 in Norway and, finally, 11,600 in Ireland. ${ }^{8}$ Compared with the numbers in the developing countries as shown above, even when taking into account the geographical size of the countries, the number in the West seems paltry in the extreme. The second controversial issue regarding the current refugee protection regime thus increasingly

\footnotetext{
4 World Refugee Survey 1992 (Washington, D.C.).

5 UNHCR, n. 3.

6 UNHCR, "UNHCR Executive Committee of the High Commissioner's Programme $50^{\text {th }}$ Session Note on International Protection", 11 International Journal of Refugee Law (1999).

7 Loescher, n. 1, at 1.

8 UNHCR, n. 3.
} 
places greater focus on the matter of sharing the burden, with collaboration between the developed and the developing worlds.

\subsection{European policies towards asylum seekers}

Ironically, in spite of the fact that developing countries assume a greater role in receiving refugees with little assistance from the developed countries, European states have steadily been restricting their asylum policies in order to lessen their obligations towards refugees. This current attitude reflects the fact that refugees are no longer of a symbolic or instrumental value to the Western states. Rather, in recent years, refugees have been perceived as burdens. ${ }^{9}$ The second reason is that countries have experienced a sudden increase of the number of refugees seeking asylum in Europe, especially from the developing world, due to recent advances in technology: from 70,000 in 1983 to 450,000 in 1990 , and to more than 288,100 in 2003 . $^{10}$

Throughout Western Europe, there is a common view that the governments fear that granting asylum to such a great number of refugees may cause social as well as political problems in their respective countries. From national perspectives, most of the European governments which have experienced an increasing problem with xenophobia are concerned that refugee inflows may adversely affect the social balance by causing racial, cultural, and religious discriminations and hostility among the locals and the refugees. Moreover, due to the increasing fear of terrorism in recent times, many people in Europe may simply be worried that some of the new arrivals might aim to attack their countries. In such circumstances, even Germany, which has for its own historical reasons been generous in taking refugees, has started to restrict its asylum policy and has amended its constitution regarding the right of asylum. ${ }^{11}$ Considered from the international point of view, on the other hand, the governments are largely concerned about international security and political interests as well as their relations with refugee-sending countries.

This European willingness to exclude asylum seekers is manifested in the course of the European common asylum policy. Originally, the idea of having a common EU asylum policy itself emerged from the single market policy - the freedom of movement of persons, goods, services, and capital among member countries of the EU - which as a result involved abolishing internal borders within the EU member states. However, this approach was shelved and blocked by a number of states wishing to retain their state sovereignty, control their own borders, and also keep asylum policy within their authority. Consequently, the agreement for the common EU asylum

\footnotetext{
9 In the face of escalating Cold War struggle, Western governments came to perceive assistance to refugees as a central part of their foreign policy, thus using foreign aid as one of the principle tools in this East-West struggle for influence. Loescher, G, The UNHCR and World Politics (Oxford: Oxford University Press, 2001), at 10.

${ }^{10}$ UNHCR, Asylum Levels and Trends 2004 (Geneva, 2004).

${ }^{11}$ Lavenex, S., The Europeanisation of Refugee Policies (Budapest: Central European University Press, 2001), at 148-184.
} 
policy, the Schengen Agreement, was finally designed to emphasize the sovereign right of internal security, public order and border controls.

The Agreement was especially formulated to restrict asylum seekers; it allowed the governments of the member states to retain state discretion and, if necessary, to send the applicant to a third state. Furthermore, it did not explicitly prohibit the return of asylum seekers to the country where their life or freedom would be threatened. It was apparent that such a principle was contrary to the 1951 Convention and other international human rights laws.

Moreover, in the context of the harmonization of European asylum policy, EU member states have been shifting away from international legal bindings by strengthening their national laws and discretion towards asylum seekers. Article 32 of the Schengen Agreement, as well as Article 3 of the Dublin Conventions, states that an application shall be processed in accordance with 'national law' in fulfilling the goal of European integration, national security and stability. ${ }^{12}$ In addition, as stated in Article 3(5) of the Dublin Convention, the so-called "safe third country policy", every contracting party to the Convention has the right to send or send back to a third country an asylum seeker before examining their application; this may occur when the state has confirmed that the third country will not send the person back to their country of origin where they may face persecution. Moreover, the party state could, through the safe country of origin strategy, simplify the application procedure of a person who comes from a country where there is in general terms no serious risk of persecution. ${ }^{13}$

Restricting internal borders and tightening refugee controls enabled each member state both to preserve its national security and stability, and to prevent inflows from other member states that hold less firm asylum policies. This "protectionist" tendency became common in Western Europe; it could be clearly observed when the Western European states prevented a massive flow even from other parts of Europe, namely, the former Yugoslavia in the 1990s. (This is discussed in Chapter 3.) Preventive action by the Western states was strengthened in particular when their governments perceived that humanitarian assistance to refugees in camps in the country of origin was financially and politically a relatively low-risk option, in contrast to the results of accepting an indefinite number of refugees or of directing political and military intervention.

However, even though these states complain about the numerous refugee influxes, the number of refugees in Western Europe is still comparatively much smaller than that in the developing countries, as shown in the previous section. It is not hard to imagine that a sudden and large-scale refugee inflow can much more seriously endanger the social and economic stability of the poorer countries than of European countries. Besides, with or without a refugee inflow, developing countries already suffer from poverty, disease, scarce economic and natural resources, unstable political structures, and ethnic and religious divisions.

12 Lavenex, n. 11, at 73.

13 Lavenex, n. 11, at 112. 
Apart from the unfavourable European policy towards refugees, the statistics of the UNHCR indicate that Western European countries became increasingly reluctant to finance the UNHCR. Instead, they spend ten times more on maintaining their own asylum system to prevent refugee inflows than on contributing to fund the UNHCR to protect refugees around the world. ${ }^{14}$ It is no doubt understandable that European governments are concerned with the impact of larger refugee inflows. However, the question arises as to whether such attitudes are relevant in the face of the fact that the cause of refugee problems is not attributable only to the refugee-sending countries; one also must consider the crucial factor that the developing countries have been struggling with a much larger number of refugees. Besides, since the governments in Europe are parties not only to the 1951 Convention and the 1967 Protocol but also to other international human rights laws, there is a question as to whether these states honour their international obligations as required by such laws. While the European governments are striving to ease their binding obligations, the duty would fall on the international community and watchdogs such as the UNHCR to lead the governments to fair, legitimate and reliable implementation of refugee protection policy. As such, it would be the UNHCR who should enforce the important role of the existing international laws and restructure the whole refugee regime in order to protect those in need. The details of the mandates of the UNHCR are discussed in the next chapter.

\section{THE UNHCR AS A REFUGEE PROTECTION BODY IN THE GLOBAL AND EUROPEAN CONTEXT}

\subsection{The 1951 Refugee Convention ${ }^{15}$ and international human rights law}

The 1951 Convention was established on 28 July 1951 to define and codify a refugee's rights and status at international level. It came into force on 21 April 1954. Since Denmark became the first state party to the Convention, a total of 145 states had by 2003 become contracting states. The Convention in Article 1A (2) defines a refugee as someone who:

As a result of events occurring before January 1951 and owing to a well founded fear of being persecuted for reasons of race, religion, nationality, membership of a particular social group or political opinion, is outside the country of his nationality and is unable, or owing to such fear, is unwilling to avail himself of the protection of that country; or who, not having a nationality and being outside the country of his former habitual resid-

14 UNHCR, http://www.unher.ch

15 For details such as the process of the establishment of the Convention, see Jackson, I., The Refugee Concept in Group Situations (The Hague: Kluwer Law International, 1999), at 11-76. 
ence as a result of such events, is unable or, owing to such fear, is unwilling to return to it. $^{16}$

As specified in the Preamble to the Convention, refugees are assured "the widest possible exercise" of all fundamental rights without discrimination, which was affirmed in the UN Charter and the Universal Declaration of Human Rights (1948). The 1951 Convention contains a wide range of rights of refugees such as the right to work, education, social security, freedom of religion, non-discrimination, access to court and other minimum standards for the treatment of refugees. This automatically requires the party states to treat refugees in the same way as they would treat aliens or their own nationals. The Convention also ensures the refugee's right to travel and exemption from visa requirements.

Moreover, the Convention prohibits states to expel a refugee to a country where he is threatened; Article 32(1) spells out that "the Contracting States shall not expel a refugee lawfully in their territory save on grounds of national security or public order." In addition, Article 33(1) of the Convention stipulates that "the Contracting State shall not expel or return (refouler) a refugee to the frontiers of territories where his life or freedom would be threatened on account of his race, religion, nationality, membership of a particular social group, or political opinion." This so-called "nonrefoulement" principle has been recognised as a rule of customary international law. Nevertheless, these protections are not infinite. Articles 1(F) and 32(2) of the 1951 Convention lay down an exclusion clause for people who have committed serious criminal offences, crimes against humanity and war crimes, acts contrary to the purpose and principles of the United Nations. ${ }^{17}$

Apart from the rights of refugees, the 1951 Convention defines some obligations and duties of the contracting states. For example, it stipulates the state's obligation to co-operate with the United Nations regarding the protection of refugees; Article 35(1) spells out that "the Contracting States undertake to co-operate with the UNHCR, or any other agency of the United Nations ... in the exercise of its functions, and shall in particular facilitate its duty of supervising the application of the provisions of this Convention." In addition, Article 35(2) requires states to provide information and data regarding the condition of refugees in their territories, implementation of the Convention, and national laws and regulations. Furthermore, Article 36 specifies the states' duty to communicate to the United Nations regarding national laws and regulations to ensure the application of the Convention and its enforcement. These

\footnotetext{
${ }^{16}$ Shah argues that in the table of negotiation regarding the Refugee Convention, the USA, France and Italy opposed recognizing non-European refugees and also refugees emerging from beyond the immediate post-war context. The UK, on the other hand, took the broadest possible definition of refugees, arguing that no restriction of time and place should be included. It did not believe that the refugee problem in the future would be a serious burden on European countries. In the end, those states which had advocated a narrow approach won and the Convention was limited by time and place. Shah, P., Refugees, Race and the Legal Concept of Asylum in Britain (London: Cavendish, 2000), at 58-59.

17 UNHCR, The Status of the World's Refugees (Oxford: Oxford University Press, 1997), at 53.
} 
state obligations specified in the provisions therefore compel party states to be legally bound to implement its asylum policy in co-operation with the UNHCR.

Sixteen years after the first comprehensive refugee law was established, the 1967 Protocol was adopted in order to adapt the 1951 Convention to the current situation. It eliminated the deadline and geographical restrictions laid down in the 1951 Convention and thus granted the UNHCR a more comprehensive competence to cover refugees all over the world; this allowed the UNHCR to provide protection to the people who became refugees due to events even after 1951. However, the most important effect of the 1967 Protocol was, as Loescher noted, that "it brought the 1951 Convention into line with the universal mandate of the Statute of the UNHCR". ${ }^{18}$

Apart from the 1951 Convention as the principal international refugee law, other international human rights instruments also provide legal rights and protection to the people fleeing their own countries and in need of protection such as the right to asylum ${ }^{19}$ and the right not to be subject to torture..$^{20}$ These provisions are often emphasized together with the 1951 Convention in order to prevent states from neglecting to protect people at risk.

\subsection{A short history of the UNHCR}

The UNHCR was established as a subsidiary organ of the General Assembly on 14 December 1950 by Resolution No. 428 of the Fifth United Nations General Assembly, which laid down the Statute of the UNHCR. The original idea of developing the international protection of refugees was initiated by the League of Nations, the predecessor of the United Nations, to protect refugees during and in the aftermath of the First World War. This League of Nations High Commissioner for Refugees (LNHCR) in office from 1921 to 1930 offered legal protection including the issue of an identity paper as well as the co-ordination of assistance to refugees. Later by 1939, the Nansen Office and the High Commissioner for Refugee replaced the LNHCR and again later, it developed into the International Refugee Organization (IRO), but this time only as an agency of limited duration.

While realizing that the post-war refugee problem could not be solved in the short term, as Salomon noted, "the western powers felt, unwillingly or willingly,

\footnotetext{
18 Loescher, n. 9, at 123-4.

19 The right to seek asylum is universally recognised in Article 14 of the Universal Declaration of Human Rights (UDHR); Everyone has the right to seek and to enjoy in other countries asylum from persecution.

${ }^{20}$ Article 3 of the Convention against Torture and Other Cruel Inhuman or Degrading Treatment or Punishment (CAT) stipulates: "No State shall expel, return ('refouler') or extradite a person to another State where there are substantial grounds for believing that he would be in danger of being subject to torture." In Chahal v. United Kingdom as a leading case, the Court held that whenever there is a substantial and real risk of being subjected to treatment contrary to Article 3 of the CAT if he is removed to another state, the state has the responsibility to safeguard him against such treatment. Chahal v United Kingdom, [1997] 23 EHRR 413.
} 
obliged to continue in one way or the other the refugee policy introduced during the Second World War." Consequently, the UNHCR was established by the UN General Assembly to continue to provide protection to refugees.

The UNHCR was, however, awarded only a limited budget to provide solely legal and political protection. ${ }^{21}$ It was initially considered that such an agency thus had to appeal to governments for material assistance and was prevented from organizing migration projects as the IRO had been able to do. As a result, the UNHCR had nothing but the competence of facilitating diplomatic pressure that it could bring upon states in order to safeguard the legal rights and interests of refugees. ${ }^{22}$

Nevertheless, until the 1980s, the UNHCR enjoyed maximum legitimacy and had a monopoly on information about refugee laws and refugee movements. Because only the UNHCR possessed specialized knowledge of and expertise in the refugee laws at that time, states simply required the UNHCR to advise on asylum matters. Nonetheless, in recent decades, the states have developed their own refugee regimes to the extent that they do not need support from other states or bodies, The UNHCR has lost its monopoly over information and expertise. In such circumstances, its authority and legitimacy in the realm of asylum have declined, in particular, since 1980 s. $^{23}$

\subsection{The principal mandates of the UNHCR}

The principal mandates of the UNHCR today can be categorized in five ways: 1) international protection, 2) emergency assistance, 3) the facilitation of voluntary repatriation, 4) the promotion of resettlement, and 5) the integration of refugees in their country of asylum. The first and primary mandate of the UNHCR is to promote, organize and supervise international protection for refugees who lack national protection, in order to safeguard their rights and interests. The objective is to ensure that refugees acquire a proper legal status as close as possible to that of the country's nationals and, further, to help them to acquire the status of citizen in order no longer to be a refugee. The UNHCR has autonomy in protection matters and intervenes with the governments on behalf of refugees, whether individuals or groups, who may be facing difficulties as a result of their status or the lack of their status. ${ }^{24}$ In order to achieve international protection for the refugees concerned, the UNHCR expedites and encourages governments to adopt appropriate provisions for the benefit of refugees and to introduce a generous policy of asylum.

\footnotetext{
21 Shah discusses that some Western European States, led by France, advocated an agency that could provide material assistance as well as legal and political protection, while the UK and the US, on the other hand, favoured an agency that could provide only legal and political protection. Shah, n. 16, at 58.

${ }^{22}$ Shah, n. 16, at 58.

23 Loescher, n. 9, at 5.

${ }^{24}$ UNHCR, Background Paper on the Office of the United Nations High Commissioner for Refugees (Geneva, 1971).
} 
The second direct activity of the UNHCR is emergency assistance for refugees in need of material support. In the course of the emergency assistance the UNHCR, in theory, works in co-operation with the host government, including providing assistance in planning and implementation, but only if invited to do so by the said government. Moreover, as specified in the Statute of the UNHCR, the UNHCR shall not appeal to governments for funds or make a general appeal for assistance to refugees without the prior approval of the General Assembly. ${ }^{25}$ This mandate, however, was not a task of the UNHCR in the early stages of the establishment of the Organization. No provision for direct material assistance for refugees was initially made at that time. Nevertheless, the UNHCR has in recent years become increasingly involved in this mandate due to the interests of the Western states; these states have become reluctant to accept refugees and so prevented refugee outflows while pressurizing the UNHCR to continue containing displaced populations in the country of origin and help them from the inside. As a result, providing emergency assistance to the displaced living in camps in their own country became, as we now can see, the second-largest component of the mandates of the UNHCR. This part of the UNHCR's evolutional duty is analyzed in Chapter 3.

Third, voluntary repatriation is considered as a primary solution to the problem of refugees, as is providing legal protection. The UNHCR makes every effort to achieve the repatriation of refugees who wish to return home. The principle of the voluntary repatriation scheme is that refugees themselves decide when to return and under what conditions. The UNHCR then supports refugees only when it has confirmed such preconditions as a fundamental change of circumstances in the country of origin, the voluntary nature of the decision to return, return in safety and dignity, and tripartite agreements between the state of origin, the host state and the UNHCR. ${ }^{26}$ Resettlement through emigration to other countries is the other solution especially favoured by many European refugees. Accordingly, the UNHCR promotes and negotiates such emigration in co-operation with the interested governments, and encourages them to liberalize their criteria for the admission of refugees. ${ }^{27}$

However, it is noteworthy that since the end of the Cold War, repatriation has been mistakenly perceived as an effective method towards reducing the number of refugees in the country of asylum. Governments, especially of the Western states that want to exclude new entrants, have exerted pressure on the UNHCR to encourage and promote the return of refugees as quickly as possible. As a consequence, the UNHCR has had no choice but to start to promote repatriations under less strict conditions than those of voluntary repatriation. In such circumstances, it cannot be denied that the beneficiaries of this repatriation policy are not primarily the refugees, but the Western states. Problems arising from the change in focus, in the light of the Western influence, within the recent repatriation policy are discussed in greater detail in Chapter 3.

\footnotetext{
25 Ibid., at 12.

26 Loescher, n. 9, at 16.

27 UNHCR, n. 24, at 17.
} 
Lastly, as the scale of refugee movements has changed since the globalization of the Cold War, integration into the country of residence has become the most realistic, practical and durable solution for refugees. As such, the UNHCR tries to facilitate the integration scheme. In theory, primary responsibility for providing aid to refugees falls upon the government, local authorities and social welfare agencies of the country where the refugees reside. However, the UNHCR helps refugees to become self-supporting in the country and so provides additional material aid only if necessary, while international protection continues to be granted to the refugees until the integration of the refugees is completed by naturalization. In the field of the material assistance at this stage, providing housing is the biggest contribution of the UNHCR. Other than that, it implements a variety of projects, such as language and cultural support in order to solve problems, to support refugees.

Nevertheless, as the UNHCR has been focusing almost entirely on repatriation and emergency relief in recent years, other crucial solutions - including international protection and local integration - have hardly been implemented as feasible options for long-staying refugee populations. The reason is very simple: the Western states, leading donors to the UNHCR, are reluctant to fund any operation other than repatriation and emergency relief. Thus, the UNHCR does not have the means to start relief operations other than these. Accordingly, it cannot be denied that some of the principal mandates of the UNHCR stipulated upon its establishment have been fading and, instead, "Western" principal mandates for refugee protection have been emerging in the face of massive donor states' influence.

Apart from direct forms of support to refugees, the mandate of the UNHCR involves a statutory function. According to paragraph 8(a) of the UNHCR Statute, the High Commissioner shall provide protection by promoting the conclusion and ratification of international conventions for the protection of refugees, supervising their application and proposing amendments thereto. Moreover, the High Commissioner is granted the competence to promote implementation of any measures for the protection of refugees through special agreement with the governments concerned. The UNHCR therefore becomes a legislative body in the sense of supervising, developing and amending international laws concerning protection of refugees. The first exercise of such undertakings was to adapt the refugee definition of the 1951 Convention to the present circumstances by initiating the form of the 1967 Protocol. The UNHCR has also participated in promoting the inclusion of provisions regarding refugees and other relevant persons into international instruments as well as into national legislations.

In addition to these core mandates of the UNHCR, the Organization should engage in such additional activities as the General Assembly may determine, alongside those as may be required by the Economic Social Council. It recognizes in Article 9 of the Statute that "the High Commissioner may, in addition to the work with refugees, engage in such activities ... as the General Assembly may determine, within the limits of the resources placed at his disposal." Hence its mandate can be highly dynamic and flexible in principle. 


\subsection{UNHCR activities in the developing countries and Western Europe}

With the main purpose of international protection of refugees, the UNHCR has been developing its mandates to meet global change since its establishment in 1951 . Although the goal of the Organization is perpetual, due to differing situations such as governmental policies or for economic reasons in respective countries, the tasks of the UNHCR in Western Europe have strikingly diverged from those in the developing countries. The latitude of mandate, responsibility, and power seems much more limited by the governments in Western Europe, on the one hand while, on the other, its duties and commitments are wider in range in the developing countries. In these circumstances, it is necessary to demonstrate and compare the activities of the UNHCR in the developed and developing countries respectively in order to clarify the reasons why the UNHCR in the West retains only restricted power, while this is not the case in the developing world. It also helps articulate the main actors who limit or facilitate the Organization's tasks in the context of protecting refugees in the state territory.

\subsubsection{The UNHCR in developing countries}

As shown in the analysis of refugee flows in Chapter 1, it can be stated that the developing countries are more generous towards refugees than are the developed countries, in the sense that the former accept a much larger number of refugees. They are also benevolent to the activities of the UNHCR since the governments in the developing countries often co-operate with the UNHCR or international agencies in accepting refugees fleeing their country. The UNHCR is welcome to be involved in a great range of activities concerning plans and implementations for refugee protection as well as arrangements of material assistance in collaboration with the host government. For example, since India is not party to the 1951 Convention and has no laws or institution on asylum, the government allows the UNHCR to deal with asylum seekers to a great extent. ${ }^{28}$ The UNHCR interviews each asylum seeker individually on behalf of the government to assess his claim to refugee status, then issues what is called the "UNHCR refugee certificate" if he is recognised as a refugee. The certificate normally leads the Indian authorities to grant an official residence permit; if not, the authority gives protection against arrest and deportation. ${ }^{29}$ Furthermore, in regard with material assistance, in 1984, the Pakistan government extensively co-operated with the UNHCR to set up a project in collaboration with the World Bank, which included re-afforestation, watershed management, irrigation, and road repair and construction for the Afghan refugees living in camps in Pakistan. It had

\footnotetext{
28 The government allows the UNHCR to deal with asylum seekers unless the reason concerns sensitive political issues. For example, the government excludes the UNHCR's involvement in asylum issues if the asylum seekers are from China, Myanmar, Bhutan, or Pakistan.

29 UNHCR, n. 17, at 59.
} 
a significant and positive impact on the extent to which many of the refugees had become self-sufficient by the late $1980 \mathrm{~s}^{30}$

The UNHCR in the developing countries also has direct access to and contact with the authorities. One of such cases is to provide financial contributions, equipment and training to police officers. To ensure the physical safety of refugees in camps, the UNHCR offers local police training and improves security in the area. Such a programme was successfully carried out in north-east Kenya, where Somali refugees were living in camps. The UNHCR took the initiative to undertake "the Women Victims of Violence Project" in order to combat the high incidence of rape and sexual violence occurring in camps, and provided special training to refugees as well as to local police in order to improve security in camps. ${ }^{31}$ Moreover, the governments in the developing countries tend to shoulder the burden of financial support to improve refugees' lives in the area of new settlement. This co-operation usually follows the government's aim to develop the region and re-invigorate local economies.

In addition to these active operations, the UNHCR is in the developing countries involved in law-making courses in co-operation with the governments. This occurs on a much broader scale than in Europe. For instance, Principles Concerning Treatment of Refugees were adopted by the Asian-African Legal Consultative Committee at its Eighth Session in Bangkok in 1966 in close co-operation with the UNHCR. Moreover, the Convention Governing the Specific Aspects of Refugee Problems in Africa (the OAU Convention) was adopted on 12 September 1969 under the aegis of the Organization of African Unity in collaboration with the UNHCR. It was decided that the OAU Convention should be a supplement to the 1951 Convention, ${ }^{32}$ and thus became favourable to the UNHCR's objectives. Furthermore, as for the protection of refugees in Latin America, the Organization co-operated in formulating the 1984 Cartagena Declaration on Refugees ${ }^{33}$ adopted in November 1984. On this occasion, the UNHCR had the opportunity to be involved in the preparation of the Declaration, obviating formal procedures within the UN or a regional organization.

In conclusion, the UNHCR has gone much further in its role in the developing countries to the degree that it has taken part in establishing national legislations and regulations concerning the protection of refugees. The Zimbabwe Refugee Act 1983, as a leading model, is now widely acclaimed to be Africa's most comprehensive and appropriate piece of domestic refugee legislation, owing to the involvement of the UNHCR. Having been drafted with the advice of the UNHCR, the Act gives

\footnotetext{
30 Ibid., at 118-120.

31 In most refugee camps, women and female children comprise 45-55\% of the whole population. Women and girls are the most vulnerable group facing gang rape and sexual violence.

32 Türk, V., "The role of UNHCR in the development of international refugee law", in Nicholson, F. et al (eds.), Refugee Rights and Realities (New York: Cambridge University Press, 1999), at 167.

33 For details, see Jackson, n. 15, at 395-414.
} 
direct effect both to the 1951 Convention and to the OAU Convention, and has been used as a model for draft legislation in Kenya, Tanzania and Swaziland. ${ }^{34}$

\subsubsection{The UNHCR in Western Europe}

Looking at the degree to which the UNHCR could affect the refugee protection regime in Western Europe, on the other hand, the main actors establishing the protection system for refugees are largely limited to the governments themselves. In the area of material assistance, for instance, unlike in the developing countries, numbers of governments are no longer prepared to finance community and social services programmes since they believe, erroneously, that such programmes might discourage refugees from going home. This seems contrary to the willingness of certain states to resolve refugee problems with the minimum of delay. Accordingly, states often prevent refugees from becoming self-sufficient and prohibit them from seeking employment, or else give them only limited access to jobs provided by the prospective employers or governmental organizations. In these circumstances, the presence of the UNHCR is barely noticeable in this field. ${ }^{35}$

In the intergovernmental as well as in the supranational levels of the refugee protection regime, and most critically, it follows that the governmental actors dominate the course of law-making despite the major mandate of the UNHCR: the supervision of international law regarding refugee protection. For instance, solely as observers, representatives of the UNHCR joined the Ad Hoc Committee of Experts on the Legal Aspects of Refugees (CAHAR), consisting of governmental experts in the fields of asylum policy mainly from its members' interior and justice ministries. The UNHCR is not entitled to an official representative to the Committee, thus does not hold the right to vote in the Committee. Moreover, in the course of the formal and intergovernmental arrangements of the EU, the UNHCR is rarely involved in the process or implementation. As a result, the UNHCR was consulted only at a very late stage of the negotiations on the final text of the Schengen Agreement. It was not allowed to participate in the due process of the Agreement or thus to function as a watchdog of the refugee protection regime. ${ }^{36}$

This tendency has been emphasized especially since the EU started building up an idea of harmonizing asylum policy; member states have been likely to restrict their policy by imposing higher criteria such as visa requirements or simply by closing the border. The states tend solely to pursue their own benefits while placing greater emphasis on sovereign rights yet not on human rights principles. The fact that, at the intergovernmental level, even suggestions and oppositions of supranational bodies such as the Council of Europe and the European Parliament became likely to be excluded further emphasizes the unequal circumstances.

\footnotetext{
${ }^{34}$ Alexander, J. and Berkowitz, N., "Hospitality or hostility? Refugee law in Africa", 12 Immigration and Nationality Law and Practice (1998), at 51.

35 UNHCR, n. 17. at 67.

${ }^{36}$ UNHCR, Briefing 16 August 1991.
} 
Apart from the Schengen Agreement, this intergovernmental phenomenon of restricting asylum policy can be seen in various law-making tactics; the EU Joint Position of 4 March 1996 on the harmonized application of the refugee definition among the member states put a narrow interpretation on its definition. It spells out that persecution by non-state agents who have no link with the state and whose activities the state is unable to control cannot constitute grounds for refugee status. In the specific context of armed conflicts, persecutory acts perpetrated by non-state agents whom the state is unable to control may be considered as persecution, but only where the perpetrators control part of the state territory. Another remarkable example is the Protocol to the Treaty Establishing the European Community on asylum for nationals of the EU member states. The Protocol places certain limits on the right to seek asylum by allowing member states to use their discretion in considering asylum applications from non-EU citizens.

These European attitudes stipulated in the previous paragraphs are obviously contrary to the UNHCR's interpretations and standards. Accordingly, the recent European policies towards refugees raise questions not only as to whether the UNHCR fulfils its mandate of supervising and developing international law concerning refugees, but also as to whether the EU member states infringe Articles 1 and 35 of the 1951 Convention by excluding the formal co-operation of the UNHCR. ${ }^{37}$

Where individual European states are concerned, there is also a growing view that their national jurisprudence has severely undermined UNHCR competence. For example, despite the states' obligation stipulated by the 1951 Convention, many of the Western European states have been increasingly straying into restricting their interpretation without consulting the UNHCR. ${ }^{38}$ In such circumstances, the fact that each Western European state develops and manipulates interpretations of the Convention, refugee definition and application of asylum at its own discretion raises tremendous questions regarding the UNHCR's raison d'être. ${ }^{39}$ Moreover, there is a fear that such domestic practices would lead both to changes in the Convention's relevance and to the competence of the UNHCR solely in this region. ${ }^{40}$

It is true that since the criteria of refugee status are not in the 1951 Convention defined in a rigid manner, there exist as many variations as there are countries. For instance, since no universally accepted definition of "persecution" exists, various interpretations are displayed; these can make all the difference in a decision of refugee

\footnotetext{
37 Türk, n. 31, at 169.

${ }^{38}$ Various commentators have noted, nevertheless, that the 1951 Convention could be interpreted more broadly, to provide protection to many individuals currently denied its benefits. See Jackson, n. 15.

39 See Arboleda, E. and Hoy, I., "The convention refugee definition in the West: a legal fiction?", 5 International Journal of Refugee Law (1999), at 66-90.

${ }^{40}$ In the Reg. $v$ Home Secretary, ex parte Sivakumaran case, the interpretation of 'well-founded fear' of persecution lay at the heart of the dispute. The Secretary of State interpreted this expression as meaning that the applicant for refugee status must establish not only fears subjectively justified but also objectively well-founded, thus rejected the applicant's asylum claim. The UNHCR was not consulted and there was no room for the UNHCR to suggest its broader interpretation. $R v$ Secretary of State for the Home Department, ex parte Sivakumaran [1987] 3 WLR 1047.
} 
status, depending on the country of asylum. Nevertheless, even under such conditions, contracting states are legally bound to take particular account of any advice from the UNHCR as to whether the interpretation is adequate under Article 35(1) of the 1951 Convention and whether the principle of non-refoulement is observed in practice. The recent European policies obviously fail to follow this principle.

Considering all factors both in the developing countries and in Western Europe, there may be various answers emerging as to why the mandates of the UNHCR are significantly limited in Western Europe while the Organization enjoys a greater role in the developing countries. One of the primary reasons is that some states in the developing countries have neither become parties to the 1951 Convention nor have adequate resources such as finance and a well-structured asylum policy to assist refugees in their countries. Therefore, they rely heavily on the UNHCR or just allow its staff to work in order to resolve refugee problems ranging from the determination of the granting of asylum to material assistance. Moreover, due to the lack of substantial finance, the developing countries tend to depend on the UNHCR to set up comprehensive assistance for the people fleeing to their countries.

However, the Western European governments, on the other hand, possess their own sophisticated asylum policy as well as enough resources to deal with refugees, within their respective capacities. As clearly seen, the states manage to tackle the refugee problems and thus do not need support from outside agencies such as the UNHCR and non-governmental bodies.

Secondly, national economic factors also constitute a significant reason. While employment is largely related to agriculture in the developing countries, this is not the case in Western Europe. Some governments in the developing countries are willing to co-operate with the UNHCR and new entrants in settling in rural areas because it is expected that such new settlers may help to develop the region, which factor as a result supports the local economy and development. For these reasons, the governments co-operate with the UNHCR to establish infrastructures, construction or schools, initially to achieve self-sufficiency for refugees but also advantageous for the host countries.

However, in Europe, by contrast, refugees often disperse rather within urban or more widely populated areas than in farming regions. Since the governments are concerned about the increasing local hostility towards refugees and vice versa, they prefer to control both the types and the numbers of jobs that refugees may obtain. As a result, those governments that want to manage national issues within their own capacity tend to exclude the outside voice from the topic of local arrangements. ${ }^{41}$

Thirdly, in particular since the idea of the harmonization of asylum policy emerged, the Western European governments keep insisting that control of national

\footnotetext{
${ }^{41}$ Nevertheless, Western states are eager to address the lack of labour force in the areas where even the native unemployed do not want to engage. On the other hand, the developing countries, sometimes the UNHCR programmes for the employment of refugees encounter opposition from the locals. For example, the UNHCR terminated a variety of programmes such as skills training at the insistence of Pakistan government, which argued that tension could develop between the refugees and the local population, who had no such programmes.
} 
borders and decisions regarding asylum matters are exclusively determined and implemented by each state itself under the right of sovereignty. This is because the governments that retain stricter asylum policy hope to avoid appeals from other governments that adhere to a less strict policy. The consequence is that all governments are trying to set a policy as rigid as possible within their discretion. In other words, certain governments are eager to retain the severe asylum policy and wish other governments to act similarly so that the former will not have to deal with new entrants coming from another European country under the freedom of movement policy. Hence, it results in the dominance of the governmental bodies and the severe exclusion of outsiders. Contrary to the Western governments, it is worth remarking that the political leaders of the developing countries are deeply concerned about their international image and have thus sought international legitimacy through their cooperation with the UNHCR. In that sense, the UNHCR could enjoy maximizing its influence or leverage to affect the behaviour of states towards refugees. ${ }^{42}$

Lastly and most prominently, the fact that the UNHCR's donors are predominantly Western European states reflects to a great extent the Organization's competence. Donors could stop supporting the UNHCR if its practice is not in accordance with the interests of the donor states. In other words, they can always prevent the UNHCR from stepping in to interfere in their asylum issues by threatening financial leverage over the Organization. Moreover, these rich states retain not only significant financial power but also strong political influence over the world. Since refugee problems involve various political factors, politically influential and authoritative states could more significantly affect the policies and mandates of the UNHCR than any other states. As a consequence, these powerful states could exclude the UNHCR whenever they choose to do so - and this is perhaps the most prominent reason why the mandate of the UNHCR in Western Europe has strikingly differed from that in the developing countries.

\section{THE TRANSITION FROM "PROTECTION" TO "REPATRIATION" AND "CONTAINMENT"}

\subsection{Constraints on the mandate of the UNHCR}

As stated in the previous chapters, the UNHCR often encounters conflicts between its international responsibilities and the limited obligations formally accepted by Western states. This dilemma is a recurring issue for the UNHCR. ${ }^{43}$ Despite its willingness to provide substantial protection to refugees, it is evident that without full co-operation from local governments and donor states, its mandate is largely restricted in scope and type. This section, in order to seek the solution towards the international protection of refugees, aims to analyze the main impediments placed on the UNHCR, which are the political problems posed by the refugee's particular

42 Loescher, n. 9, at 5.

43 Türk, n. 31, at 165 . 
characteristics and, secondly, the extensive financial contribution to the UNHCR by Western states.

As for the first obstacle, the political facet of refugee issues, the UNHCR encounters great difficulties when states are unwilling to receive refugees in their territories. Since there is no country to which refugees could escape without any authoritative permission, the UNHCR always needs formal consent from the local government of the territory. Nevertheless, there has hardly ever been a time when states offered asylum without some form of political calculation or discrimination. ${ }^{44}$ While refugee policies could be used to deny refugee status to nationals of a friendly state and will often imply foreign policy support for the sending government on the one hand, the decision to bestow formal refugee status on citizens of a particular state, on the other hand, usually implies condemnation of the sending government for persecuting its citizens. ${ }^{45}$ Taking into account the fact that refugee problems involve to a great extent the respective internal politics of each state, it is inevitable that the operations of the UNHCR are restrained when encountering the negative co-operation from a government.

In addition, as the UNHCR itself admits, it normally needs to rely on the authorization of the host government to implement operations in the field, and so is ultimately incapable of obliging others to respect international refugee law. ${ }^{46}$ Because the Organization's task in protecting refugees is restricted to non-political actions enshrined in its Statute, it is not possible that without the government's consent, the Organization could go further in enlarging its mandate in their territories.

A further major factor that impedes the UNHCR from implementing genuine protection policies is the governments' insistence on the rights of sovereignty. As governments wish to retain their power in controlling the entry and the number of foreign citizens, they stress the importance of their right of sovereignty and thus successfully exclude outsiders. Such an example is clearly laid down in the EU common asylum policy as described in Chapters 1 and 2.

The second factor severely to limit the ability of the UNHCR in defending the rights of the refugee is that the UNHCR is part of the United Nations system, a political organ guided and financed by donations from its member states. As the majority of these donations come from the developed states, in particular the Western states, the UNHCR is obliged to depend on these states for its survival. According to the UNHCR publication showing major contributors in 2003, the largest donors were the United States and Japan, which provided US\$259,244,770 and \$117,969,877 respectively. Fourteen states out of the top twenty sponsors were Western European: the European Commission $(\$ 70,754,484)$, the Netherlands $(\$ 61,210,482)$, Sweden $(\$ 42,457,288)$, Norway $(\$ 38,731,557)$, the United Kingdom $(\$ 33,560,724)$, Denmark $(\$ 33,731,660)$, Germany $(\$ 30,560,090), \quad$ Switzerland $(\$ 16,326,268)$, Italy $(\$ 13,809,819)$, Finland $(\$ 11,953,196)$, and France $(\$ 10,711,140) .{ }^{47}$

${ }^{44}$ Loescher, n. 9, at 16.

45 Loescher, n. 1, at 37.

46 UNHCR, n. 17 , at 80.

47 UNHCR, n. 3. 
In line with each state's political interests, donor states often use their financial influence in order to exert control over the UNHCR. An apparent example can be seen when the massive Afghan exodus occurred into the neighbouring countries after the Soviet Union's invasion of Afghanistan in December 1979. While the donor states contributed vast sums of money to assist Afghan refugees in Pakistan, they provided little for the Afghans in Iran even though these refugees comprised one of the world's largest refugee populations at the time. It was because relations between Iran and the Western states - in other words, donor states - were strained to the limit due to the 1979 Islamic revolution as well as to the assault on the US Embassy in Teheran in 1979. In such circumstances, the donor states were unwilling to assist the refugees in Iran; in turn, Iran decided not to seek international or what it perceived as "Western" help. ${ }^{48}$

Another striking example is when the UNHCR fell into a financial crisis because of the dramatic increased number of refugees in the 1980s and the promotion of expensive large-scale repatriation programmes. The donor governments took advantage of the situation and seized on this shortfall to bring the Organization under their direct financial control. The donor governments refused to cover the deficit and insisted that the UNHCR should base its operation on the funds that were available, instead of on the needs of refugees. Consequently, there was no alternative or compromise solution that the UNHCR could have adopted for the protection of refugees; it merely followed what the Western states required. As a result, there was a complete breakdown of confidence between the donor states and the UNHCR. ${ }^{49}$ To summarize: as long as the UNHCR depends on financial support from the Western states, it is difficult to imagine that the Organization would be able to enjoy complete freedom of action without taking those states' views into account.

\subsection{Shifting from genuine "protection" policies}

As mentioned in the previous section, due to the great financial contribution by the powerful Western states, it is clear that the UNHCR's policies and activities are, as a result, largely influenced by these states. In effect, the UNHCR has been compelled to come closer to the Western approach and has developed its policy in accordance with the wishes of those states. In recent years, it can be clearly seen that the UNHCR has shifted from its original "Protection" policy focus to "Repatriation"- and "Containment"-oriented policies, which apparently suit the purposes and interests of the donor states. These measures are carried out in order to prevent refugee flows into their territories and, directly and indirectly, to reinforce their non-

48 Later, when Iran faced another massive refugee flow from Iraq during the war in Iraq, the government officially requested UNHCR assistance because of their lack of finance to assist refugees. UNHCR, n. 17, at 117-8.

49 Loescher, n. 9, at 263. 
entrée policy. ${ }^{50}$ Ironically, these new approaches focus on the responsibilities of the refugee-sending countries and hence place heavier burdens on the poorer states within the international system. The new measures have, moreover, helped to facilitate temporary protection policies, where refugees are granted only limited rights and protection.

Western-oriented approaches exert a considerable influence on the shape of the international legal framework and jurisprudence. Chimni precisely noted in this context, "the (Western) dominant ideology tends to present itself as the common sense of the age and therefore often goes uncontested (in the international community)." As a result, the policies of the UNHCR, led by Western states, justify the new approaches to the rest of the international community by carefully shifting its mandate in accordance with the interests of the Western states in practice. ${ }^{52}$ It can follow, in conclusion, that the international legal issues regarding refugee protection are highly dependent on the political priorities of the leading donor states which control the UNHCR's lifeline, ${ }^{53}$ and that these subsequently override the Organization's "nonpolitical agency" principle.

The UNHCR has adopted the "Repatriation" scheme in co-operation with the Western governments in the context of repatriation of the Tamil asylum seekers. The "Containment" policy, on the other hand, was highlighted in Afghanistan, Iraq and Bosnia-Herzegovina. These cases are examined in the following sections.

\subsection{1. "Repatriation" policy focus}

The crucial shift of the UNHCR from a "Protection"- to a "Repatriation"-oriented policy focus became apparent when the number of the Tamil asylum seekers increased in Europe. By the year 1987, in spite of restrictive measures imposed by the UK government, the number of the Tamils arriving in Britain from Sri Lanka, a former British colony, expanded; it was at this time that the UNHCR switched its policy towards repatriation.

The British government then in power argued that, since there had been no objective evidence of persecution of the Tamils generally or any particular group of the Tamils or the applicants in Sri Lanka, the rejected Tamils were without scrutiny of individual cases legitimately being sent back to Sri Lanka. This severe repatriation policy implemented by the British government towards the Tamils was emphasized throughout Europe through co-ordination with other European states who also wanted to control the movement of the Tamil asylum seekers and to prevent the influx of

\footnotetext{
${ }^{50}$ Given that Vietnamese refugees are the last case of non-European refugees accepted as part of an international protection scheme in 1975, Western states have started focusing on repatriation especially since numbers of Tamil refugees have emerged.

${ }^{51}$ Chimni, B.S., "The geopolitics of refugee studies: a view from the South", 11 Journal of Refugee Studies (1998), at 371.

52 See the details, ibid., at 350-374.

53 As Chimni noted, "the thinking of international organisation is shaped by its more powerful members, especially if they control the financial lifeline." Ibid., at 371.
} 
asylum seekers into their territories. Such motivation led those European states, together with North American governments, to influence the UNHCR not to accord the applicants Convention status, and to adopt a cooperative attitude in repatriation programmes for the Tamils. ${ }^{54}$

The repatriation scheme was supported by the UNHCR especially after 1986, when the UNHCR took a decisive turn through the appointment of a new High Commissioner, Jean-Pierre Hocke, ${ }^{55}$ at the insistence of the United States. Later, Hocke appointed Jonas Widgren, Swedish Deputy Minister for Immigration, as the Co-ordinator for the Inter-Governmental Consultations. ${ }^{56}$ It is worth mentioning that the appointments were made when the Western donor governments perceived the UNHCR to be both too closely focused on protection issues in Europe and in North America, and inadequately concerned with managing refugee programmes in the developing countries. In particular, the United States criticized the UNHCR and campaigned strenuously for a new High Commissioner who would be more "operational" and who would have a more "hands-on" approach to refugee problems. ${ }^{57}$

The new High Commissioner, supported by the West, consequently shifted UNHCR policy towards closer co-operation with North American and European states. Moreover, Hocke himself had from the beginning of his appointment believed voluntary repatriation to be the only realistic alternative to indefinite subsistence on charity. In such circumstances, human rights groups feared that it would accelerate the European restrictive policies, especially towards the Tamils who were a matter of concern at that time. They also criticized the Organization's involvement in the repatriation of the Tamils, questioning its ability to provide substantive protection for them upon their return. Moreover, it was argued that the position of the UNHCR on the Tamils' repatriations might eventually encourage involuntary repatriation by those European states who wished to exclude Tamils from their territories. Indeed, following Widgren's statement that the UNHCR hoped to enforce repatriation and return 500 young Tamils from Europe ${ }^{58}$ the repatriation program was facilitated by some European states such as France and the Netherlands.

Nevertheless, this new policy, backed by Western governments and the UNHCR, inflicted severe hardships on some Tamil asylum seekers; this subsequently attracted international attention. In February 1988, some Tamils, whose applications had been

\footnotetext{
54 Shah, n. 16, at 151.

55 Hocke was the Swiss Director of Operations at the International Committee of the Red Cross. He resigned as High Commissioner in October 1989 after huge criticism of his arbitrary management and a financial crisis. Ibid., at 155 .

${ }^{56}$ When Hocke appointed Widgren, he believed that this would increase his leverage with Western governments. On the other hand, UNHCR officials perceived this as a deliberate undermining of the Europe bureau and as a sign of the UNHCR's capitulation to European governments. Following this appointment, it marked a loss of the UNHCR's influence and legitimacy in Europe over the asylum issue. Loescher, n. 9, at 250.

57 There was no question that the UNHCR at that time was more highly esteemed by many donor governments, particularly the United States, which sought its relief operations rather than its protection of refugees, Loescher, n. 9, at 250.

58 Shah, n. 16, at 156.
} 
dismissed by the Lords in the Sivakumaran case, ${ }^{59}$ were returned to Sri Lanka on the grounds that there was no objective evidence of persecution that may have occurred in Sri Lanka. Later, four of them were found to have been persecuted upon their return. They then launched an appeal to an adjudicator and won their appeals from Sri Lanka. Finally, in 1989, the five of the applicants were granted entry clearance and returned to the UK. Subsequently, the applicants in this case appealed to the European Commission of Human Rights.

As far as the international judiciary is concerned, it is noteworthy that this Western-oriented repatriation scheme had a significant influence even on the decisions of the international judiciary, particularly on the European Commission of Human Rights. In the case of Vilvarajah and others $v . U K,{ }^{60}$ the Commission rejected, by a majority of eight to one, a claim by the applicants in the above Sivakumaran case that the UK government had violated Article 3 of the European Convention on Human Rights (ECHR: prohibition against torture) despite the clear evidence of persecutions which had been inflicted on the applicants upon their return to Sri Lanka.

What is more, the Commission upheld the repatriation scheme, stating that the policy was a strong indication that the situation in Sri Lanka had improved sufficiently for repatriation. Further, it found that the applicants were not in a worse situation than were the generality of other Tamils in Sri Lanka, thus recognized the consideration of the Secretary of State as substantive. Considering the fact that there was apparent evidence of persecutions upon their return, the European human rights machinery also seemed to support, or be influenced by, the Western-interested view towards non-European asylum seekers and thus did not reject the repatriation itself. ${ }^{61}$ Last but not least, the Commission left the issue of the legitimacy of the repatriation policy ambiguous, such that it has facilitated further repatriation measures in Western Europe.

Hocke's continuous insistence that repatriation was the only viable alternative to the current refugee problem, while stressing that the refugee problem costs Western donor states too much, earned the backing of the Executive Committee, which encouraged the High Commissioner to look for opportunities to promote repatriation. It provided the UNHCR with the legislative mandate to exploit political openings to promote repatriation, even into areas where active conflicts were still taking place. ${ }^{62}$ Since 1992, the UNHCR has further developed its repatriation policy towards the Tamils, despite their fears as to whether it would guarantee substantive protection for returnees in Sri Lanka. Recently, the UNHCR carried out a repatriation programme in co-operation with the governments of Switzerland and Sri Lanka based on the view that the Tamils and the Sinhalese refugees whose asylum applications had been rejected could be safely returned to the south of Sri Lanka.

The UNHCR's active involvement in the repatriation programme has, as McDowell argued, directly influenced asylum granting procedures in the Western states

\footnotetext{
$59 R v$ Secretary of State for the Home Department, ex parte Sivakumaran, [1987] 3 WLR 1047.

60 Vilvarajah and others $v$ UK, 14 European Human Rights Reports (1992), at 248.

61 Shah, n. 16, at 157-8.

62 Loescher, n. 9, at 252.
} 
faced with high numbers of the Tamil asylum seekers; furthermore, the repatriation agreement backed by both the Western states and the UNHCR would make it difficult for a Sri Lankan national to prove that he or she was genuinely in fear of persecution. ${ }^{63}$ It is clear that in the case of the Tamils, the UNHCR repatriation programme was directed in favour of the Western European states under the influence of the UNHCR policy makers appointed by the leading donor states. By carrying out the Western-supported approach, the UNHCR has hence helped to create and justify new procedural and substantive laws set up from the Western point of view. In other words, it has helped in guiding both the nature of the UNHCR and the international refugee law in a different direction.

The Tamil asylum seekers are one instance; the UNHCR also sought repatriation of other nationals to the Horn of Africa and Central America. The promotion of repatriations in both areas gave rise to problems because refugees were returning to theatres of either on-going conflict or of political tension. In such circumstances, it became highly controversial as to whether the UNHCR did in fact coerce refugees to return to their respective home countries. Even after Hocke left office, further development of repatriation policy was intensively pursued through various practices under High Commissioner Sadako Ogata, who also made repatriation a primary objective of the Organization. ${ }^{64}$

In sum, repatriation policies have shifted to be based more strongly on pragmatic considerations and less on protection principles. For example, the UNHCR has developed terminology and concepts such as 'safe return', where conditions in the home country did not have to improve 'substantially' but only 'appreciably' so that nationals should be returned to the country of origin; ${ }^{65}$ during the Kosovo crisis in the former Yugoslavia in the 1990s, the UNHCR co-operated with the Western states in implementing an involuntary repatriation scheme that replaced the notion of 'safe return' ${ }^{66}$ It is clear that this concept is contradictory to the principle that repatriation must be based on a strictly voluntary decision by refugees and has to guarantee their return in safety and dignity.

In such circumstances, it cannot be denied that the UNHCR has been practising a repatriation policy according to the interests of the leading donor states, while these various repatriation operations gave rise to tremendous doubt that refugees could indeed be satisfactorily protected in the country of asylum where they were unwanted by host governments; rather, protection required freeing refugees from the country of asylum and finding ways for them to return to their home countries as quickly as possible even if it occurred under less than ideal circumstances.

63 Shah, n. 16, at 159.

64 She was appointed High Commissioner in December 1991. From 1991 to 1996, over nine million refugees were repatriated to their homes in such countries as Namibia, Somalia, Ethiopia, Cambodia, Mozambique, Afghanistan, and Angola: seven times greater than the number between 1985 and 1990.

65 Loescher, n. 9, at 284.

66 Chimni, n. 50, at 365. 
Accordingly, the UNHCR appears to have lost its focus on protection along with some of its autonomy and independence. As a consequence, such UNHCR practices have led not only the Western states but also other states that also want to discourage entirely refugee movement to misuse, even abuse, this new preventive policy. There is no question that the UNHCR, in such circumstances, seems unable to oppose forced repatriation, given the absence of stronger support from the international community. ${ }^{67}$

\subsection{2. “Containment” policy focus}

The containment policy approach is designed to assist the displaced persons from inside their country of origin while preventing refugee outflows from there. It relies on material assistance rather than on international protection. Together with the repatriation-oriented focus, this containment policy has successfully attracted the Western states since it can be used to prevent refugees from entering their countries and as a result, the number of refugees could be reduced in Western Europe. The containment-oriented policy appeared significant in the cases of Afghanistan, Iraq and Bosnia in the 1990s, when the UNHCR adopted this so-called "in-country protection scheme" rather than insisting on the importance of protection in the country of asylum, usually assumed to be the Organization's primary mandate.

Regarding the first case, Afghanistan, as Pakistan closed its border to prevent Afghan refugees from flowing into the country, the UNHCR was obliged to set up camps across southern Afghanistan to receive numerous refugees fleeing from the capital. This action resulted in reducing pressure upon Pakistan to accept refugees. In effect, Pakistan has refused to open its borders to any new refugees except the most needy even after the US bombing campaign started in 2001. Although the UNHCR condemned Pakistan's decision to close the border, it was helpless to do anything to divert the flow of refugees elsewhere outside of Afghanistan. As a result, the UNHCR ended up solely continuing to provide humanitarian assistance to those who were displaced within the borders of Afghanistan whilst still under dangerous conditions. ${ }^{68}$

The second example of the containment policy was when a mass displacement of Kurds occurred in Iraq following the Gulf War in 1991. No condemnation was made by the United Nations when the Turkish government closed its border in its own interests; rather, it sympathized with the Turkish government, which feared the threat of destabilization of the region from the influx of refugees. The United Nations thus indirectly supported Turkey's refusal to accept refugees. The Western states, under pressure from the public's demand for protection for those displaced Kurds, decided to carry out containment measures; they requested the UNHCR to provide protection to the Kurds in camps, largely located throughout the mountainous regions

${ }^{67}$ Landgren, K., "The future of refugee protection", 11 Journal of Refugee Studies (1998), at 427.

68 In 1999, crowds enraged by the prospect of UN sanctions against the Taliban regime went on the rampage against UNHCR facilities and burned UNHCR offices located in Afghanistan. UNHCR, www.unhcr.ch. 
along the border of Iraq and Turkey, whilst refusing to force Turkey to accept the Kurds. They then announced that they were preparing with the use of NATO force ${ }^{69}$ a "safe zone" in northern Iraq to receive refugees. The UNHCR was left with no option but to provide humanitarian assistance to the displaced.

The third most prominent UNHCR in-country protection policy was implemented during the time of war in the former Yugoslavia in the 1990s. It was most striking among the recent operations in the sense that, unlike other situations where refugee flows occurred, this tragic event was considerably influenced by the foreign policies of Western European states and their efforts to prevent refugee flows from the country geographically close to their territories. To limit the potential occurrence and effects of refugee flows, the Western European states imposed great pressure upon the UNHCR to pursue the containment protection method. Under those circumstances, it is worth remarking that contributions from the Western states increased dramatically to the extent that total UNHCR expenditure more than doubled between 1990 and $1993 .^{70}$

Moreover, the fact that European states made it clear that they intended to control and pre-empt the arrival of refugees in their territories ${ }^{71}$ compelled the UNHCR to adopt the containment policy focus. At the same time, the then High Commissioner, Sadako Ogata, however, perceived as an opportunity to render the Organization relevant to the international community's most powerful actors the UNHCR's engagement with the Western-interested approach. ${ }^{72}$ As a result, the UNHCR pursued strategies whereby it set up camps mainly at state borders to contain the displaced within the territory whilst providing humanitarian assistance to those in need. Needless to say, this policy successfully prevented people from becoming refugees simply by virtue of the fact that they could not flee their country of origin. In other words, the policy thus indirectly helped to reduce the number of refugees in Western Europe.

The last and most striking case was eastern Bosnia-Herzegovina, where a large number of Muslims was forcibly displaced and completely surrounded by Serbian military forces supporting the "ethnic cleansing" of Muslims. In 1993, the international community decided to establish a "safe haven" in the area, the similar term also used as "safe areas" in the northern Iraq for the Kurds. Under an agreement with Serbian authorities, the UN Security Council ensured that the UNHCR was able to grant humanitarian assistance to the Muslims without any threat of armed attack. Nevertheless, the situation in the camps was considered worse. Moreover, the UNHCR found

69 It was obvious that the security of Kurdish population in 'safe areas' was far from guaranteed and the needs for emergency relief did not always meet the requirements due to severe geographical conditions.

70 Total expenditures increased from $\$ 296,518,600$ in 1992 to $\$ 532,362,900$ in 1993 . It was greater than expenditures for the entire African continent $(\$ 325,141,000)$. Barutciski, M., "The reinforcement of non-admission policies and the subversion of the UNHCR: displacement and internal assistance in Bosnia-Herzegovina (1992-1994)", 8 International Journal of Refugee Law (1996), at 92.

71 In 1992, owing to special tie with the country, Germany admitted over 100,000 refugees from the former Yugoslavia, the highest number among the EU states. A total of only 3,000 refugees were admitted by France and the UK. See the details, Barutciski, n. 69, at 73.

72 Loescher, n. 9, at 296. 
it difficult to secure the protection of human rights and the physical security of the displaced people in the camps. It thus became obvious that those displaced people were a most vulnerable group. They could go nowhere to find refuge outside of the territory, while not only the Western European states but also their own authorities, in their own interests, prevented them from leaving the enclaves. ${ }^{73}$ To add to the worsening of the situation, the UNHCR ended up withdrawing its operation from the region due to the increasing risks to its personnel.

As can be seen in these cases mentioned above, it is clear that in-country protection is not efficiently implemented to protect civilians especially in the middle of a war, where humanitarian assistance to the displaced persons relies solely on military action and co-operation from warring states; the stories from Kosovo highlight the difficulty of ensuring the protection of human rights and the physical security of displaced persons when their camps are located within areas of on-going conflict. Although the UNHCR tried to establish a presence to monitor human rights abuses and carry out its protection activities, warring parties often hindered the UNHCR from visiting areas where ethnic cleansing was taking place and the staff were unable to prevent the harassment of minorities. Moreover, the containment policy focus led the UNHCR to work not only with the governments but also with opposition groups, guerrilla forces, political factions, and clan leaders, as well as with UN peacekeeping and military intervention forces. As a result, there was a growing view that the UNHCR has been largely involved beyond its competence in political factors influencing refugee problems, and that its operation in protecting the displaced differed substantially from its principle to protect refugees in the country of asylum. ${ }^{74}$

Nevertheless, as the UNHCR had to adapt its approach in order to balance the expectations of the donor states with the reality of people's being displaced, the containment policy focus was sought as a compromise method by the Organization itself. It thus expanded its mandate to cover those displaced, and struggled to establish legitimacy by creating a new notion known as the 'protection of the IDPs' (Internally Displaced Persons), according to which the IDPs must be protected, within the UNHCR's capacity, for humanitarian purposes. ${ }^{75}$ The legal basis for the operations for protection of the IDPs was provided by the General Assembly Resolution, which acknowledged the UNHCR's particular humanitarian expertise, together with Article 9 of its Statute. Nevertheless, given the UNHCR's statutory responsibility as an independent actor representing the interests of refugees, the question arises as to whether the containment policy was sought within its mandate, and whether it was

\footnotetext{
73 See Barutciski, n. 69, at 84-88.

74 Traditionally, the internally displaced persons (IDPs) were not included at the time the 1951 Convention was set up. It is because the IDPs were seen as falling under the domestic jurisdiction of the state concerned. As a result, the IDPs remained without effective protection or assistance. 75 It was argued by the Executive Committee that the UNHCR should involve itself in a broad range of policies touching on issues formerly considered domestic and therefore too political. Protection, the core activity of the UNHCR's mandate, could take many forms, including the provision of relief assistance to civilians caught in conflicts. Loescher, n. 9, at 269.
} 
the most appropriate organization to carry out such programmes. ${ }^{76}$ Furthermore, the issue of whether the growing number of IDPs and the increasing UNHCR practice of enacting preventive policies in the light of the way donor states and the UNHCR are interacting with each other warrants attention. ${ }^{77}$

What should also be emphasized in the Kosovo case is that, not coincidently, the UNHCR adopted a containment-oriented measure when the European states articulated that they intended to control and pre-empt the arrival of asylum seekers in their territory. In this sense, it cannot be denied that the practice of the UNHCR in the former Yugoslavia was propitious for the Western European states wishing to prevent cumbersome refugee flows. Although the UNHCR stressed that prevention protection implementation was not a substitute for asylum, it made it easier for a government to justify its denial of admission. As a consequence, a fear arises as to whether these UNHCR practices will lead the states to implement this new containment approach whenever they discern the threat of a massive refugee inflow into their territories. Especially since the Western states were willing to resist assisting people fleeing violence even from other parts of Europe, it is not difficult to imagine their view towards others in need of protection fleeing from the developing countries. In summary, a series of the events in the former Yugoslavia concludes that, as Goodwin-Gill has precisely stated, “[the] UNHCR's strategy was directed away from protection of refugee strictly so-called, to the more idealistic political goal of preventive solutions."78

\section{CONCLUSION}

\subsection{Consequences of the UNHCR's preventive policies}

As a consequence of these various practices, the UNHCR's Western-oriented policies give rise to considerable problems in both legal and practical contexts. Primarily, "Repatriation" and "Containment" policies are not in accordance with the UNHCR Statute, since the UNHCR has no legal authority to protect persons within their own country. Moreover, there is no international customary law as such, and no locus standi. When facing legal difficulties in providing protection to the people in need, the UNHCR has nevertheless often evolved its roles while relying on socalled "good office" concepts; it depends on consensual arrangements outside the

\footnotetext{
${ }^{76}$ Critics have argued that the UNHCR's activities for the IDPs may be misinterpreted as obviating the need for international protection and asylum. It is also argued that a blurring of the distinction between refugees, who enjoy additional rights under international refugee law, on the one hand, and the IDPs, on the other, would undermine the protection of refugees themselves. UNHCR, The State of the World's Refugees (Oxford: Oxford University Press, 2000), at 215.

${ }_{77}$ There were 1,200,000 IDPs in Afghanistan, 683,300 in Sri Lanka, 438,300 in Bosnia-Herzegovina in 2001 according to the UNHCR, Refugees by numbers (2001).

${ }^{78}$ Goodwin-Gill, G., "Refugee identity and protection's fading prospect", in Nicholson, F. et al. (eds.), Refugee Rights and Realities (New York: Cambridge University Press, 1999), at 226.
} 
rule of law, hence they are always negotiable by states at will. ${ }^{79}$ In such circumstances, there is no doubt that the mandate of the UNHCR will always be negotiable and thus will remain susceptible to manipulation by powerful states for them to meet their wishes. Accordingly, the fear lies in the extent to which the UNHCR's role in "the protection of refugees" will be compromised following such manipulation in the face of the Western states' interests.

Secondly, "Repatriation"- and "Containment"-oriented measures have forced the UNHCR to become involved in political discourse, which is outside of the Organization's guiding principles. Both policies have forced the UNHCR to engage in political discussion where it was obliged to negotiate with warring states for humanitarian access, or was used in these states' interests. If the influential Western states continue to direct the UNHCR to adopt these new preventive approaches, as well as compelling the Organization to negotiate within political rather than humanitarian scenarios in order to meet their demands, the assumption is that the ability of the UNHCR to fulfil its primary responsibility as a non-political agency will ultimately be nullified.

Thirdly, repatriating refugees on the grounds that there is no risk in their country of origin automatically raises the question as to whether the country of asylum violates the provisions against torture or non-refoulement. On the other hand, containing refugees in camps within the country of origin would deny them their right of asylum in and access to another territory, which are the principal rights as internationally recognized. While implementing Western-oriented policies, there is a doubt that the UNHCR itself may attenuate international legal obligations conferred upon states. What is more important is that these policies apparently put in danger those people most in need of protection.

Lastly, the claim that both these Western-oriented policies and the perspective of the Western European states have imposed more and greater burdens on the developing countries from which refugees are fleeing seems justified and thus cannot be avoided. Since the Western European states are reluctant adequately to fund the UNHCR unless the Organization adopts policies that suit their interests, the UNHCR tends to be obliged to implement policies such as the "Repatriation" and "Containment" measures when a massive refugee movement occurs. The West's preventive policies would result in other less restrictive countries', or the neighbouring countries of the refugee-sending country thus usually the developing countries', having to accept more refugees. Hence, the developing countries alone and despite their limited capacity shoulder the major burden of providing protection to refugees.

Accordingly, these countries have also begun tending towards preventive protection policies simply by closing borders when they can no longer afford to host refugees (Pakistan against the Afghan refugees, and Turkey against the Kurds, for example.) These countries will need to be convinced that the richer states will share the economic, social and political burdens imposed by large movements of refugees. If they feel the richer states are interested only in passing the buck back to them, it can easily be imagined that they will stop co-operating in the protection of refugees.

79 Ibid., at 246. 
If the developing countries, which have so far been generous towards refugees, also start to follow the practices of the Western states as justified by the UNHCR, the assumption is that "international protection of refugees" would hold less meaning and, further, that the UNHCR would engage solely in offering humanitarian assistance, which is not considered as the principal mandate of the UNHCR. For these reasons, it cannot be denied that the fear exists that, for as long as the UNHCR follows Western-oriented policies, not only would more people fleeing violence be in danger, but also that the UNHCR's whole raison d'être would be in jeopardy.

\subsection{Reconsidering the UNHCR}

As noted in the previous sections, one of the problems which hinder the UNHCR from acting independently and outside the influence of the Western states is its reliance on voluntary contribution. The UNHCR depends on voluntary donations from the member states of the United Nations, as noted in Chapter Three. It is obvious that the Western European states will not support the UNHCR if the latter carries out operations they do not favour. On the other hand, these states are willing to fund the UNHCR as long as its policies reflect their sovereign interests. This can be specially seen in the Bosnia case where the total UNHCR expenditure on the former Yugoslavia amounted to more than that on the whole of the African continent. Goodwin-Gill has suggested that this dependence on the contributions of states wishing to influence the UNHCR has "significantly undercut its capacity for independent or objective thought and action." As long as the UNHCR depends on voluntary finance by states for its survival, it may be assumed that the Organization cannot help continuing to be influenced by the leading donor states ${ }^{80}$ Finding realistic alternatives to the relationship between the reliance on voluntary contributions and the UNHCR's operations should, however, be more widely discussed.

The second problem that the UNHCR needs to take into account is the fact that the UNHCR usually collaborates with Western academics, research institutions and lawyers, rather than with those from the developing states. ${ }^{81}$ It may be a fact that facilities and databases are far better structured in the developed countries, yet since most refugees are generated in the developing countries, it can be deemed inappropriate to share ideas and policies only among the developed countries. Moreover, Western experts sometimes aim to deliver the perspectives held by their own governments and could thus indirectly shape the policies of the UNHCR. It is both advisable and necessary for the UNHCR to explore refugee problems from the point of view of the developing states in order for refugees' needs and solutions to be discussed within a much wider perspective. Hence, collective and reliable data and information

${ }^{80}$ Goodwin-Gill accuses the UNHCR of its inability to pursue what the international community wants. In his book, he criticizes dependence on voluntary contributions as this practice apparently enslaves the UNHCR.

81 Chimni, n. 50. 
from both the developed and developing states should be demanded in determining refugee policy.

Thirdly, it is urgently required that the UNHCR co-operate more closely with those European supranational actors who urge the genuine protection of refugees, such as the Council of Europe, instead of co-operating with the governments and facilitating the preventive protection schemes. In that sense, it is crucial that the Western governments should also reflect the voices from supranational regimes, and from Western and local NGOs in their policy-making process.

Fourthly, at the institutional level, the need for transparency and accountability in UNHCR implementations should be urged. It is inevitable for the UNHCR to open up its operations to scrutiny by other institutions such that they can prevent the UNHCR from focusing too closely on the preventive policy, a system not in the interests of refugees. For example, in Tanzania, several NGOs reported that the UNHCR had promoted repatriating refugees under less appropriate conditions, and in a less open and transparent process. ${ }^{82}$ It is apparent, therefore, that the UNHCR should consider establishing solid relationships with NGOs, academics, and other humanitarian institutions instead of solely pursuing the co-operation with governmental bodies.

Lastly, for all actors involving in refugee issues, it is necessary to sustain solidarity and internationalism among states, the UNHCR, and other international humanitarian organizations, as well as NGOs. While the UNHCR and other humanitarian organizations are co-operating in exchanging various opinions and views, this process must prevent governments from focusing on preventive policies and, rather, direct them towards refugee-centred protection policies.

\subsection{Towards future operations}

Under High Commissioners Hocke and Ogata, it is not too much to say that the UNHCR lost sight of its traditional protection principles, in the face of pressure from the influential Western states. At the same time, a new set of rules and practices emerged during their mandates that stressed greater state control over refugee and asylum admissions; limited access to asylum procedure, and humanitarian aid over protection. These combined to erode the rights of refugees.

In January 2001, Ruud Lubbers, a former Dutch Prime Minister, became the ninth High Commissioner for Refugees. He took over its already well-established repatriation policy focus thus following previous High Commissioners. When he was appointed High Commissioner, most European governments were still deeply concerned about the increasing number of asylum seekers in their territories. Such European concerns were articulated when the UK government, which aimed at halting the growing numbers of Afghan asylum seekers coming to the UK, signed a tripartite agreement for the voluntary repatriation of Afghans residing in the UK, and with

82 Goodwin-Gill, n. 77, at 246. 
the government of Afghanistan and the UNHCR for their re-integration back into Afghanistan in October 2002. ${ }^{83}$ The UNHCR's co-operation with this repatriation policy was ensured by Lubbers, who encouraged sustainable repatriation on a 'voluntary basis' with other European states, while there was a view that terrorist/rebel attacks were still common in Afghanistan and US forces were still battling remnants of the ousted Taliban regime. ${ }^{84}$

One month later, EU ministers drove to set up a plan for 1,500 Afghan refugees every month to be repatriated from the EU region. ${ }^{85}$ Moreover, in April 2003, the UK government began enforced deportations of a group of refugees to Afghanistan, as it believed conditions in the country had improved and the return of refugees should be secured. It is estimated that the governments carrying out the repatriation of Afghan refugees believed that the return of the refugees to Afghanistan was legitimate even when done forcibly, on the basis that the repatriation policy backed by the UNHCR gave assurances that Afghanistan had already become safe. In other words, the governments believed that Afghan refugees must be returned to their country of origin since the UNHCR had officially confirmed that the situation was improved; the UNHCR's apparent confirmation could clearly be seen in its cooperation with the governments in facilitating this repatriation.

Nevertheless, although security and stability in Afghanistan were not assured, the High Commissioner was generally upbeat about the importance of continuing the repatriation process. ${ }^{86}$ Loescher argued that Lubbers's challenges would include countering the decline in the willingness of states to provide asylum to refugees, securing a strong and permanent basis for financing UNHCR activities, and reforming the UNHCR to make it a more effective and accountable organization; ${ }^{87}$ however, the assumption, while looking at recent UNHCR operations, is that such accomplishments are far too unrealistic. Unless the UNHCR itself becomes aware that preventive policies cannot be a genuine solution, there is always a fear that even a comprehensive international refugee organization whose purpose was, and still is, to provide international protection to people fleeing persecution will fail to protect the human rights

\footnotetext{
83 According to the UNHCR UK Office's statistics, Afghan refugees comprised the third-largest number of populations seeking asylum in the UK, amounting to 7,380 in 2002, while 199,900 Afghan refugees arrived in Pakistan. UNHCR, http://www.unhcr.org.uk.

${ }^{84}$ In addition to the military action, and the destruction and neglect of Afghanistan's agricultural and economic infrastructure due to the internal conflict, Afghans were confronted with the effects of drought. The drought has severely affected 2.5 million farmers, caused deprivation to over a million people, and caused massive displacement within and from Afghanistan. However, despite such situations in Afghanistan, Lubbers planned to repatriate 4,113,000 Afghan refugees solely from neighbouring states by December 2002. UNHCR, http://www.unhcr.ch.

${ }^{85}$ It was estimated that there were up to 400,000 Afghans living in Europe, both legally and illegally. UNHCR UK, http://www.unhcr.org.uk.

${ }^{86}$ Some of the largest security problems have been in the northern regions of Afghanistan, where rivalries between local commanders and the harassment of minorities, especially Pashtuns, have flared up periodically since the occupying Taliban forces were pushed out of the north in the autumn of 2001.

${ }^{87}$ Loescher, n. 9.
} 
of refugees. If the UNHCR were to decide simply to become an international organization providing food and other humanitarian aid, serious questions upon the UNHCR's raison d'être would arise. 